AmericA THE FAIR 



\title{
AMERICA THE FAIR
}

\section{Using Brain Science to Create a More Just Nation}

\author{
Dan MeEgan
}


Copyright @ 2019 by Cornell University

Lyrics to "We Can Talk" copyright $@ 1968$ by Dwarf Music. All rights reserved. International copyright secured. Reprinted by permission.

All rights reserved. Except for brief quotations in a review, this book, or parts thereof, must not be reproduced in any form without permission in writing from the publisher. For information, address Cornell University Press, Sage House, 512 East State Street, Ithaca, New York 14850.

Visit our website at cornellpress.cornell.edu.

First published 2019 by Cornell University Press

Printed in the United States of America

Librarians: a CIP record is available from the Library of Congress.

ISBN 978-1-5017-3547-9 (pbk. : alk. paper)

ISBN 978-1-5017-3548-6 (pdf ebook)

ISBN 978-1-5017-3549-3 (epub/mobi ebook)

Ebook edition 2019 
For America with love 
